\title{
A halophilic thermophilic bacterium isolated from a coastal hot spring in Lutao, Taiwan
}

\author{
WUNG YANG SHIEH* \\ Institute of Oceanography, National Taiwan University, PO Box 23-13, Taipei, Taiwan, Republic of China
}

(Received 10 March 1993; accepted 21 April 1993)

\begin{abstract}
A heterotrophic, moderately thermophilic bacterial strain, designated strain T501, was isolated from a hot spring on the coast of Lutao, Taiwan. This bacterial strain was a strictly aerobic, Gram-negative rod, normally $0.6-0.7 \mu \mathrm{m}$ in diameter and $4-10 \mu \mathrm{m}$ in length, and motility was achieved by one to several lateral flagella. Its minimum and maximum growth temperatures were approximately 30 and $60^{\circ} \mathrm{C}$, respectively, with an optimal temperature at about $50{ }^{\circ} \mathrm{C}$. The $\mathrm{G}+\mathrm{C}$ ratio of its DNA was $38.1 \mathrm{~mol} \%$. Strain $\mathrm{T} 501$ tolerated a $\mathrm{pH}$ range from 6 to 9. It was halophilic, growing optimally in about $2 \%$ (w/v) salt, and $\mathrm{Na}^{+}$was indispensable unless $\mathrm{Mg}^{2+}$ or $\mathrm{Ca}^{2+}$ were available. The addition of either cation to $\mathrm{Na}^{+}$-sufficient media significantly enhanced growth. Halophilic heterotrophic bacteria capable of aerobic growth over a temperature range of $40-55{ }^{\circ} \mathrm{C}$ have not been reported previously.
\end{abstract}

\section{Introduction}

Micro-organisms growing optimally at temperatures higher than $45^{\circ} \mathrm{C}$ are considered to be thermophiles, the majority of which are members of either Archaea or Bacteria (Brock, 1985; Stetter et al., 1990). Those growing optimally at temperatures of more than $80^{\circ} \mathrm{C}$ are called hyperthermophiles, and are usually unable to grow below $60^{\circ} \mathrm{C}$. The most extremely thermophilic species grow at temperatures between 80 and $110^{\circ} \mathrm{C}$ (Stetter et al., 1990) and are strictly anaerobic archaea. Salt-dependent hyperthermophilic archaea of various genera have been isolated from shallow-water or deepsea submarine hydrothermal areas (Fiala et al., 1986; Kurr et al., 1991; Miroschnichenko et al., 1989; Neuner et al., 1990; Pledger \& Baross, 1989, 1991; Pley et al., 1991). The genus Thermotoga includes the most thermophilic members of Bacteria, which may grow in environments up to $90^{\circ} \mathrm{C}$ (Stetter et al., 1990). Salt is absolutely essential for three species of this genus (Huber et al., 1986; Windberger et al., 1989). A variety of aerobic and anaerobic thermophilic bacteria, mainly heterotrophic species, have been described besides Thermotoga spp. (Kristjansson, 1992). All of them, however, only grow below $80-85^{\circ} \mathrm{C}$. Rhodothermus marinus, found in shallow-water submarine hot springs, is presently the

* Tel. 88623630231 ext. 2162; fax 88623626092. only aerobic halophilic heterotroph among them (Alfredsson et al., 1988). It requires approximately $2 \%(\mathrm{w} / \mathrm{v})$ salt and a temperature of $65^{\circ} \mathrm{C}$ for optimal growth. Many thermophilic strains of Thermus spp. with an optimal growth temperature of $70-75^{\circ} \mathrm{C}$ and a minimum growth temperature of about $55^{\circ} \mathrm{C}$ will grow in the presence of salt at $3 \%$ or higher (Kristjansson et al., 1986), but they are halotolerant rather than halophilic since their growth is not stimulated by salt. Several halotolerant thermophilic species of Bacillus grow between 40 and $65^{\circ} \mathrm{C}$ (Claus \& Berkeley, 1986). They do not require salt for growth but tolerate a salt concentration of $2-7 \%$.

A halophilic, strictly aerobic, thermophilic heterotroph has been isolated in this laboratory in a study of thermophilic bacteria in the coastal hot springs of Lutao, Taiwan. This strain differs from all known species of halophilic thermophilic bacteria. The isolation and characterization of this micro-organism are described here.

\section{Methods}

Sample collection. Lutao is a small island $\left(\mathrm{ca} 16 \mathrm{~km}^{2}\right)$ in the Pacific Ocean, 19 miles south-east of Taiwan. Several hot springs on the southeastern coast and the intertidal zone around this island are slightly acidic and saline due to the mixture of underground and/or surface seawater. The temperature in the hot-water ducts of different springs ranges from 50 to $90^{\circ} \mathrm{C}$. A water sample, which had an original 
temperature of $59^{\circ} \mathrm{C}$, was collected from the opening of a hot spring on the coast at a depth of about $10 \mathrm{~cm}$.

Media. The peptone-yeast (PY) broth medium used for enrichment consisted of $4 \mathrm{~g}$ Bacto-peptone (Difco), $2 \mathrm{~g}$ Bacto-yeast extract (Difco), $25 \mathrm{~g} \mathrm{NaCl}$ and $0.5 \mathrm{~g} \mathrm{MgCl}_{2} .6 \mathrm{H}_{2} \mathrm{O}$ in 1 litre deionized water and adjusted to $\mathrm{pH} 7 \cdot 0$. $\mathrm{PY}$ broth supplemented with $\mathrm{CaCl}_{2}\left(10 \mathrm{mg} \mathrm{l}^{-1}\right)$ and $\mathrm{MnCl}_{2}$ was used to detect endospore formation. PY agar was prepared by adding $20 \mathrm{~g}$ agar (Difco) to 1 litre PY broth. This medium was supplemented with Tween $80(0.001 \%)$ and $\mathrm{CaCl}_{2}\left(0.1 \mathrm{gl}^{-1}\right)$ for the lipase test. Four modified PY agar media containing casein $\left(4 \mathrm{~g} \mathrm{l}^{-1}\right)$, starch $\left(4 \mathrm{~g} \mathrm{l}^{-1}\right)$, gelatin $\left(4 \mathrm{~g} \mathrm{l}^{-1}\right)$ and DNA $\left(2 \mathrm{~g}^{-1}\right)$, respectively, were used to test the hydrolysis of these substrates.

The peptone-yeast-carbohydrate (PYC) broth media were prepared from two stock solutions: (1) $4 \mathrm{~g}$ Bacto-peptone, $2 \mathrm{~g}$ Bacto-yeast extract, $25 \mathrm{~g} \mathrm{NaCl}, 0.5 \mathrm{~g} \mathrm{MgCl}_{2} .6 \mathrm{H}_{2} \mathrm{O}$ and $4.5 \mathrm{~g} \mathrm{MOPSO}$ (Sigma) dissolved in $900 \mathrm{ml}$ deionized water and adjusted to $\mathrm{pH} 7.0$; and (2) $5 \mathrm{~g}$ of glucose, galactose, saccharose, cellobiose, xylose, mannose, trehalose, lactose, mannitol or dulcitol dissolved in $100 \mathrm{ml}$ deionized water. The two solutions were autoclaved separately and mixed at room temperature. The modified PYC broth media used for carbohydrate fermentation tests were prepared from two stock solutions: (1) $4 \mathrm{~g}$ Bacto-peptone, $2 \mathrm{~g}$ Bacto-yeast extract, $0.03 \mathrm{~g}$ bromothymol blue, $25 \mathrm{~g} \mathrm{NaCl}, 0.5 \mathrm{~g} \mathrm{MgCl}_{2} .6 \mathrm{H}_{2} \mathrm{O}$ and $0.6 \mathrm{~g}$ Tris ( $\mathrm{ca} 5 \mathrm{mmol}$ ) dissolved in $900 \mathrm{ml}$ deionized water and adjusted to $\mathrm{pH} 7 \cdot 4$; and (2) $5 \mathrm{~g}$ of one of the above carbohydrates (see composition of PYC broth media) was dissolved in $100 \mathrm{ml}$ deionized water.

Mineral media containing $\mathrm{NH}_{4} \mathrm{Cl}\left(0.1\right.$ or $\left.0.5 \mathrm{~g} \mathrm{l}^{-1}\right)$ as the sole nitrogen source and various carbohydrates $\left(5 \mathrm{~g}^{-1}\right)$ as the sole carbon sources were modified from Shieh et al. (1988). MOPSO instead of Tris was added to the mineral media at $20 \mathrm{~mm}$, and the $\mathrm{pH}$ of these media was adjusted to 7.0. Three media used for the tests of arginine dihydrolase, lysine decarboxylase and ornithine decarboxylase were modified from Falcow lysine decarboxylase broth (MacFaddin, 1980). They consisted of $4 \mathrm{~g}$ Bacto-peptone (Difco), $2 \mathrm{~g}$ yeast extract, $0.5 \mathrm{~g}$ glucose, $25 \mathrm{~g} \mathrm{NaCl}, 0.5 \mathrm{~g} \mathrm{MgCl} .6 \mathrm{H}_{2} \mathrm{O}, 0.02 \mathrm{~g}$ bromocresol purple, and $5 \mathrm{~g}$ of L-arginine, L-lysine or L-ornithine, respectively, in 1 litre deionized water and adjusted to $\mathrm{pH} 6.8$. All $\mathrm{pH}$ adjustments were made with $\mathrm{HCl}(1.0 \mathrm{M}), \mathrm{KOH}(1.0 \mathrm{M})$ or both.

Isolation of thermophilic bacteria. The water sample was serially diluted with a sterile $\mathrm{NaCl}-\mathrm{MOPSO}$ buffer $(25 \mathrm{~g} \mathrm{NaCl}$ and $0.45 \mathrm{~g}$ MOPSO in 1 litre deionized water, $\mathrm{pH} 7 \cdot 0$ ). The cultures for enrichment of thermophilic bacteria were prepared by inoculating portions $(1 \mathrm{ml})$ of $10^{0}-10^{5}$ dilutions of the water sample into tubes containing PY broth $(5 \mathrm{ml})$. They were incubated at $50^{\circ} \mathrm{C}$ in the dark for $2-5 \mathrm{~d}$ under aerobic conditions. The cultures that developed an $\mathrm{OD}_{600}$ of greater than 0.2 were used $(10 \mu \mathrm{l})$ to inoculate fresh PY broth $(5 \mathrm{ml})$ for a secondary enrichment cultivation, streaked (one loopful) on PY agar plates and incubated aerobically at $50{ }^{\circ} \mathrm{C}$ in the dark for $2-3 \mathrm{~d}$. Various types of colonies appearing on the plates were picked off and purified by successive streaking on PY agar. The cultures were maintained in both PY agar and PY broth and stored at $50^{\circ} \mathrm{C}$. One strain, designated as T501 was used in this study.

Characterization of thermophilic isolate. One loopful of culture was inoculated into $5 \mathrm{ml}$ of each of the carbohydrate fermentation media, and the air in each culture tube was replaced by Ar after sealing with a rubber stopper. The cultures were examined daily for colour changes for up to $7 \mathrm{~d}$. The cultures for the tests of arginine dihydrolase, lysine decarboxylase and ornithine decarboxylase were also incubated anaerobically under Ar and were examined for colour changes after incubation for $7 \mathrm{~d}$. Cells cultivated at 50 or $55^{\circ} \mathrm{C}$ in the modified PY broth medium were observed daily for endospores with a phasecontrast microscope for $7 \mathrm{~d}$ by spore staining (Smibert \& Krieg, 1981). Luminescence, pigmentation, swarming and agarase (Agbo \& Moss,
1979) were determined after growth for $24-48 \mathrm{~h}$ on PY agar plates. Luminescence was recorded after the plates had been in the dark for $5 \mathrm{~min}$. Casein hydrolysis, amylase, gelatin hydrolysis, lipase and DNAase were tested by methods similar to those of Smibert \& Krieg (1981). Tests for oxidase, catalase and Gram reaction were performed on cells grown for $2448 \mathrm{~h}$ on PY agar plates (Shieh et al., 1988). Cells grown for $2448 \mathrm{~h}$ in PY broth were observed for motility by phasecontrast microscopy and fixed with $3 \%(\mathrm{v} / \mathrm{v})$ glutaraldehyde and negatively stained with potassium phosphotungstate $(1 \%, \mathrm{w} / \mathrm{v}, \mathrm{pH} 7 \cdot 0)$ for electron microscopy. All test cultures were incubated at $50^{\circ} \mathrm{C}$ in the dark for $5 \mathrm{~d}$ under aerobic conditions unless otherwise stated.

Determination of antibiotic sensitivity. Sensitivity to the following antibiotics was determined with discs (Difco): ampicillin $(10 \mu \mathrm{g})$, chloramphenicol $(30 \mu \mathrm{g})$, erythromycin $(15 \mu \mathrm{g})$, gentamicin $(10 \mu \mathrm{g})$, kanamycin $(30 \mu \mathrm{g})$, nalidixic acid $(30 \mu \mathrm{g})$, penicillin $\mathrm{G}$ (10 units), polymyxin B (300 units), streptomycin $(10 \mu \mathrm{g})$, tetracycline $(30 \mu \mathrm{g})$. Discs were placed on PY agar plates which had been spread with $0.1 \mathrm{ml}$ culture of strain T501. Inhibition zones around the discs were measured after overnight incubation at $50^{\circ} \mathrm{C}$ under aerobic conditions.

Test for diaminopimelic acid. The presence or absence of diaminopimelic acid in the cell hydrolysates $\left(4 \mathrm{M}-\mathrm{HCl}, 16 \mathrm{~h}, 100^{\circ} \mathrm{C}\right)$ of strain T501 were determined by paper chromatography (Rhuland et al., 1955).

DNA base composition. The $\mathrm{G}+\mathrm{C}$ content of bacterial DNA was determined by HPLC of nucleosides formed by P1 hydrolysis (Shieh $e t$ al., 1987).

Determination of the effects of various factors on growth. Strain T501 was routinely precultivated in PY broth. One loopful of early stationary-phase preculture was inoculated into a tube containing $5 \mathrm{ml}$ PY broth or its modifications, to determine the effects of temperature, $\mathrm{pH}, \mathrm{Na}^{+}, \mathrm{Mg}^{2+}$ and $\mathrm{Ca}^{2+}$ on growth. The mineral media were used for the determination of growth on single carbon sources. The effects of various carbohydrates on growth were determined in PYC broth media. Bacterial growth was monitored by measuring culture optical density using a Spectronic 20 spectrophotometer (Milton Roy Company) at $600 \mathrm{~nm}$. All growth experiments were carried out at $50^{\circ} \mathrm{C}$ in the dark under aerobic conditions unless otherwise stated.

\section{Results}

\section{Characterization of thermophilic micro-organism}

Strain T501 was a rod-shaped, motile, Gram-negative bacterium, $0.6-0.7 \mu \mathrm{m}$ in diameter and 4-10 $\mu \mathrm{m}$ in length. Motility was achieved by one to several lateral flagella. Endospore formation was suspected since it did not grow above $65^{\circ} \mathrm{C}$, but survived at $80^{\circ} \mathrm{C}$ for several h to $1 \mathrm{~d}$. Endospore-like structures were observed with a low frequency $(<10 \%)$ at the centre of the unstained cells but sporulation was not confirmed by spore staining. Cells grown on PY agar for $1 \mathrm{~d}$ developed circular, slightly umbonate, non-pigmented colonies with an entire margin. None of the test carbohydrates (glucose, saccharose, galactose, mannose, lactose, cellobiose, trehalose, xylose, mannitol dulcitol) were fermented. Additional physiological and biochemical characteristics are listed in Table 1.

Diaminopimelic acid was detected in the cell hydrolysates of strain T501, it was sensitive to all 10 of the test 
Table 1. Characteristics of strain T501

\begin{tabular}{lc}
\hline \hline Characteristic & Reaction* \\
\hline Gram stain & - \\
Anaerobic growth & - \\
Halophilism & + \\
Motility & + \\
Growth at: & - \\
$25^{\circ} \mathrm{C}$ & + \\
$40-555^{\circ} \mathrm{C}$ & - \\
$65^{\circ} \mathrm{C}$ & - \\
Luminescence & - \\
Pigmentation & - \\
Swarming & + \\
Casein hydrolysis & - \\
Agarase & + \\
Oxidase & w \\
Catalase & - \\
Lipase & - \\
Gelatinase & w \\
Deoxyribonuclease & - \\
Amylase & - \\
Arginine dihydrolase & - \\
Lysine decarboxylase & - \\
Ornithine decarboxylase & \\
\hline \hline
\end{tabular}

${ }^{*}+$, Positive; - , negative; $\mathrm{w}$, weakly positive.

Table 2. Sensitivity of strain T501 to various antibiotics

\begin{tabular}{lc}
\hline \hline Antibiotic & $\begin{array}{c}\text { Inhibition zone } \\
\text { width (mm)* }\end{array}$ \\
\hline Ampicillin & 19 \\
Chloramphenicol & 12 \\
Erythromycin & 12 \\
Gentamicin & 12 \\
Kanamycin & 8 \\
Nalidixic acid & 10 \\
Penicillin G & 20 \\
Polymyxin B & 5 \\
Streptomycin & 3 \\
Tetracycline & 18 \\
\hline
\end{tabular}

* From the edge of the discs to the edge of bacterial growth. All data represent mean values of duplicate experiments.

antibiotics (Table 2) and had a $\mathrm{G}+\mathrm{C}$ content of $38 \cdot 1$ $\mathrm{mol} \%$.

\section{Effects of temperature, $p H$ and carbon sources on growth}

Strain T501 grew significantly in PY broth over a range of $40-55^{\circ} \mathrm{C}$, and rapidly at about $50^{\circ} \mathrm{C}$, to an $\mathrm{OD}_{600}$ of more than 0.2 within $1 \mathrm{~d}$. The growth rate was significantly lowered at 30 to $35^{\circ} \mathrm{C}$ and the $\mathrm{OD}_{600}$ of the cultures was only about $0 \cdot 1$ even after incubation for $2 \mathrm{~d}$. Strain T501 grew weakly $\left(\mathrm{OD}_{600}<0 \cdot 1\right)$ or not at all at $60{ }^{\circ} \mathrm{C}$ after up to $7 \mathrm{~d}$ incubation, but some replicate cultures exhibited significant growth. No growth oc-
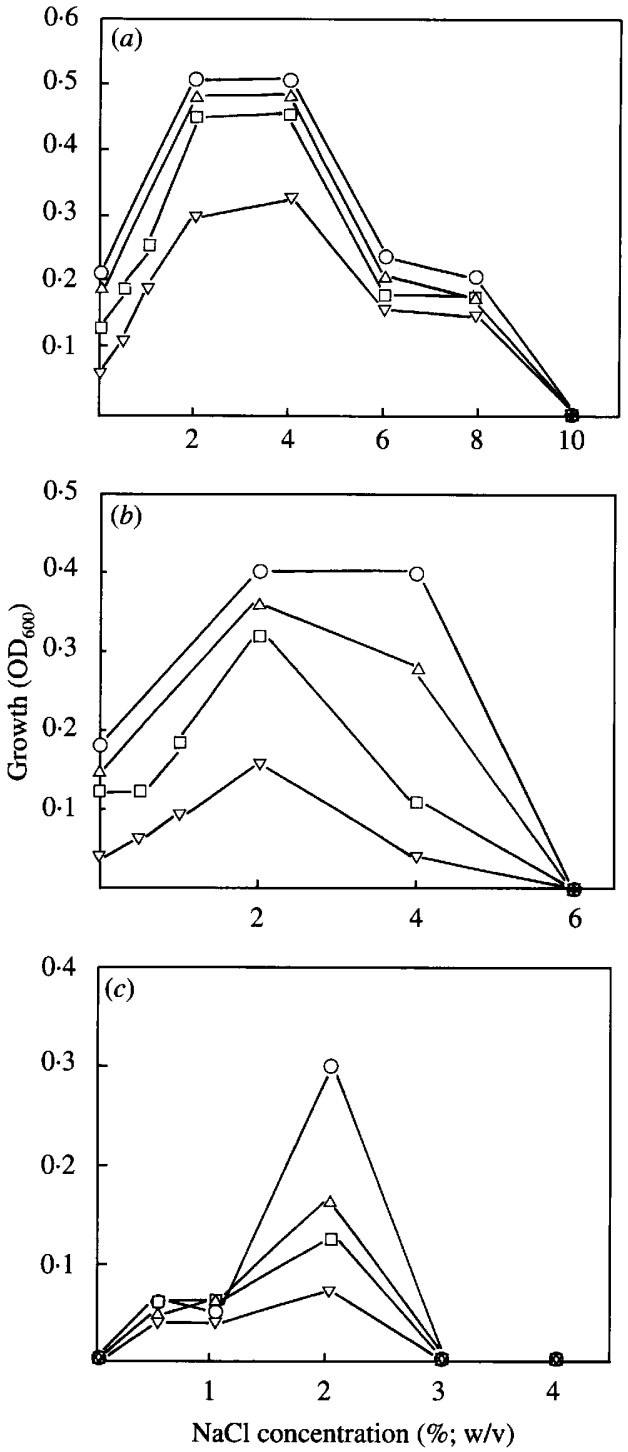

Fig. 1. Influence of salt concentration on growth of strain T501 in modified PY broth media supplemented with $2.5 \mathrm{mM}-\mathrm{Mg}^{2+}(a), 2.5 \mathrm{mM}-$ $\mathrm{Ca}^{2+}(b)$ or neither of the two bivalent cations $(c)$. $\mathrm{OD}_{600}$ was measured at $24(\nabla), 48(\square), 72(\triangle)$ and $96 \mathrm{~h}(O)$ as shown. Each point represents the mean of five cultures.

curred at 25 or $65^{\circ} \mathrm{C}$. Strain T501 tolerated a variation of $\mathrm{pH}$ from 6.0 to $9 \cdot 0$, but growth did not occur at $\mathrm{pH} 5 \cdot 0$ or 10.0 . No growth occurred in any of the mineral media aerobically or anaerobically, nor in PY or any of the PYC broth media under anaerobic $(100 \% \mathrm{Ar})$ conditions.

\section{Effects of $\mathrm{Na}^{+}, \mathrm{Mg}^{2+}$ and $\mathrm{Ca}^{2+}$ on growth}

Strain T501 grew in $0-8 \%$ salt $(\mathrm{NaCl})$ in media containing $2.5 \mathrm{~mm}-\mathrm{Mg}^{2+}$, with the most rapid and maximal growth at $2-4 \%$ salt (Fig. $1 a$ ). Growth did not occur at higher than $6 \%$ salt if $\mathrm{Ca}^{2+}(2.5 \mathrm{~mm})$ instead of 
$\mathrm{Mg}^{2+}$ was added to the medium (Fig. $1 b$ ). The $\mathrm{NaCl}$ tolerance range was more narrow in media deficient in $\mathrm{Mg}^{2+}$ and $\mathrm{Ca}^{2+}$. Without these cations, significant growth $\left(\mathrm{OD}_{600}>0 \cdot 1\right)$ occurred only in about $2 \%$ salt; growth was weak in $0.5-1 \%$ salt and even negligible outside the salt concentration range between 0.5 and $3 \%$ (Fig. $1 c$ ). Substitution of $\mathrm{KCl}(1-4 \%)$ for $\mathrm{NaCl}$ did not support bacterial growth if $\mathrm{Mg}^{2+}$ and $\mathrm{Ca}^{2+}$ were not added (not shown). The presence of $0.025-0.25 \mathrm{mM}-\mathrm{Mg}^{2+}$ or $\mathrm{Ca}^{2+}$ could not support the growth of bacteria under saltdeficient conditions (not shown). All concentrations of the cations $\mathrm{Na}^{+}, \mathrm{Mg}^{2+}, \mathrm{Ca}^{2+}$ and $\mathrm{K}^{+}$quoted here represent the minimal concentrations of these ions due to their presence in complex media used in these experiments.

\section{Discussion}

Moderately thermophilic bacteria with temperature optima of 40 to $60^{\circ} \mathrm{C}$ and unable to grow above $70^{\circ} \mathrm{C}$ had been isolated prior to the 1960s (Brock, 1984; Kristjansson, 1992). None of them were halophilic, although a few moderately thermophilic species of the genus Bacillus exhibited halotolerant characteristics (Claus \& Berkeley, 1986). The moderately thermophilic strain T501 isolated in this study could be considered as moderately halophilic since its optimal growth occurred at about $2 \% \mathrm{NaCl}$. Strain T501 required $\mathrm{Na}^{+}$but not $\mathrm{Cl}^{-}$for growth under conditions deficient in $\mathrm{Mg}^{2+}$ and $\mathrm{Ca}^{2+}$. The requirement for $\mathrm{Na}^{+}$could not be satisfied by $\mathrm{K}^{+}$, indicating that the requirement was not an osmotic function. The presence of $\mathrm{Mg}^{2+}$ or $\mathrm{Ca}^{2+}$ at a concentration of $2.5 \mathrm{~mm}$ allowed strain T501 to grow under $\mathrm{Na}^{+}$-deficient conditions, indicating that either cation could substitute for the $\mathrm{Na}^{+}$requirement of this bacterium. $\mathrm{Na}^{+}$was not an efficient substitute of $\mathrm{Mg}^{2+}$ and $\mathrm{Ca}^{2+}$ since $2.5 \mathrm{mM}-\mathrm{Na}^{+}$was not nearly as effective as either of the two divalent cations at the same concentration (Fig. 1). Moderately halophilic bacteria (mesophiles or psychrophiles) in the marine environment generally require 70 to $700 \mathrm{mM}-\mathrm{Na}^{+}$for optimal growth and yield (Reichelt \& Baumann, 1974; Baumann \& Baumann, 1977; Baumann et al., 1983, 1984a,b). This requirement for $\mathrm{Na}^{+}$can be reduced but not replaced by the addition of a certain concentration of $\mathrm{Mg}^{2+}$ and $\mathrm{Ca}^{2+}$ (Reichelt \& Baumann, 1974). Strain T501 is thus the first halophilic bacterium exhibiting a requirement for $\mathrm{Na}^{+}$ that can be replaced by $\mathrm{Mg}^{2+}$ or $\mathrm{Ca}^{2+}$, although $\mathrm{Na}^{+}$with either $\mathrm{Mg}^{2+}$ and $\mathrm{Ca}^{2+}$ was necessary for the most rapid and maximal growth.

$\mathrm{Na}^{+}$is required in mesophilic halophilic bacteria for a number of complex and essential cellular functions. This includes permease systems involved in the uptake of exogenous substrates (Drapeau et al., 1966; Forsberg et al., 1970; Thompson et al., 1970; Thompson \& MacLeod, 1974; Fein \& MacLeod, 1975), the retention of solutes within the cells (Wong et al., 1969) and the maintenance of cell wall integrity (Forsberg et al., 1970). $\mathrm{Na}^{+}$has also been found to stimulate the activities of amylase (Onishi, 1972) and cytochrome oxidase (Kushwaha et al., 1977) in mesophilic halophilic bacteria. Whether $\mathrm{Na}^{+}$has any of the above functions in cells of strain T501 remains to be investigated.

Strain T501 is a strict aerobe that did not ferment any of the carbohydrates tested, nor did it grow anaerobically in PY or any of the PYC broth media. None of the carbohydrates tested could be utilized as the sole carbon source.

The majority of Gram-negative bacteria as well as most species of the genus Bacillus contain a peptidoglycan of the directly cross-linked diaminopimelic acid type (Claus \& Berkeley, 1986; Schleifer \& Kandler, 1972). The cell wall peptidoglycan of strain T501 may also belong to this type since diaminopimelic acid has been detected from the cell hydrolysates of the strain.

Strain T501 has been excluded from the genus Bacillus (Claus \& Berkeley, 1986) on the basis of its halophilic and Gram-negative properties, and its lateral flagellation. The characterization that strain T501 is a motile, nonpigmented halophile, which is unable to grow at temperatures above $70^{\circ} \mathrm{C}$ shows it is not a species of the genus Thermus (Brock, 1984). Halophilic heterotrophic eubacteria are almost all mesophilic or psychrophilic, but few are thermophilic. They include species of the genera Rhodothermus (Alfredsson et al., 1988), Thermotoga (Huber et al., 1986; Jannasch et al., 1988; Windberger et al., 1989), Thermosipho (Huber et al., 1989) and Spirochaeta (Aksenova et al., 1992). Strain T501 cannot be placed in any of the latter three genera since none of them include strict aerobes. Rhodothermus marinus, the only aerobic species of halophilic thermophilic heterotrophs reported, has a minimum growth temperature at about $55^{\circ} \mathrm{C}$. Strain T501 is thus the first halophilic heterotrophic bacterium capable of aerobic growth at temperatures between 40 and $55^{\circ} \mathrm{C}$. It has a $\mathrm{G}+\mathrm{C}$ content of $38.1 \mathrm{~mol} \%$, far lower than Rhodothermus marinus. This, together with other data (Table 3), may be sufficient to propose a new genus for the strain, but a formal proposal will not be made until the sequence data of 16S and/or 5S rRNA have been obtained.

The author has isolated more than $\mathbf{4 0}$ bacterial strains of aerobic, halophilic, thermophilic heterotrophs from the coastal hot springs of Lutao, a few of which, like strain T501, can grow under $\mathrm{Na}^{+}$-deficient conditions in the presence of $2.5 \mathrm{mM}-\mathrm{Mg}^{2+}$ or $-\mathrm{Ca}^{2+}$ (unpublished data). They are, however, somewhat more thermophilic than strain T501; their optimum and maximum growth temperatures are approximately 55 to $60{ }^{\circ} \mathrm{C}$ and 65 
Table 3. Characteristics distinguishing strain T501 from Rhodothermus marinus

\begin{tabular}{lcc}
\hline \hline Characteristic & Strain T501 & $\begin{array}{c}\text { Rhodothermus } \\
\text { marinus* }\end{array}$ \\
\hline Growth at: & & \\
$40-50^{\circ} \mathrm{C}$ & + & - \\
$65-70^{\circ} \mathrm{C}$ & - & + \\
Motility & + & - \\
Pigmentation & + & - \\
Oxidase & + & - \\
Casein hydrolysis & + & - \\
Sensitivity to: & + & - \\
Streptomycin & + & - \\
Kanamycin & 38.1 & 64 \\
Gentamicin & & \\
G+C content (mol \%) & & \\
\hline \hline
\end{tabular}

* Data from Alfredsson et al. (1988).

to $70{ }^{\circ} \mathrm{C}$, respectively (unpublished data). Halophilic thermophilic bacteria closely related to strain T501, as well as these isolates, may be confined to a very narrow zone near the openings of coastal or submarine hot springs due to the requirement for oxygen, organic matter, a moderately high temperature and the metal cations $\mathrm{Na}^{+}, \mathrm{Mg}^{2+}$ and $\mathrm{Ca}^{2+}$.

The author wishes to thank Dr J.-S. Chen for critical reading of the manuscript, Miss P. P. Chang, Food Industry Research and Development Institute, for determining the DNA base composition, and M. L. Jong and W. D. Jean for assistance. This work has been supported by a grant from the National Science Council, Republic of China (NSC81-0211-B002a-501).

\section{References}

AgBo, J. A. C. \& Moss, M. O. (1979). The isolation and characterization of agarolytic bacteria from a lowland river. Journal of General Microbiology 115, 355-368.

Aksenova, H. Y., Rainey, F. A., Janssen, P. H., Zavarzin, G. A. \& Morgan, H. W. (1992). Spirochaeta thermophila sp. nov., an obligately anaerobic, polysaccharolytic, extremely thermophilic bacterium. International Journal of Systematic Bacteriology 42, $175-177$.

Alfredsson, G. A., Kristjansson, J. K., Huörleifsdottir, S. \& STETTER, K. O. (1988). Rhodothermus marinus, gen. nov., sp. nov., a thermophilic, halophilic bacterium from submarine hot springs in Iceland. Journal of General Microbiology 134, 299-306.

BaumanN, L., Bowditch, R. D. \& BaUmanN, P. (1983). Description of Deleya gen. nov. created to accommodate the marine species Alcaligenes aestus, A. pacificus, A. cupidus, A. venustus and Pseudomonas marina. International Journal of Systematic Bacteriology 33, 793-802.

Baumann, P. \& BaumanN, L. (1977). Biology of the marine Enterobacteria: genera Beneckea and Photobacterium. Annual Review of Microbiology 31, 39-61.

Baumann, P., Furniss, A. L. \& LeE, J. V. (1984a). Genus I. Vibrio Pacini 1854, 411 $1^{\mathrm{AL}}$. In Bergey's Manual of Systematic Bacteriology, vol. 1, pp. 518-538. Baltimore: Williams \& Wilkins.

Baumann, P., Gauthier, M. J. \& BaumanN, L. (1984 b). Genus Alteromonas Baumann, Baumann, Mandel and Allen 1972, $418^{\mathrm{AL}}$. In Bergey's Manual of Systematic Bacteriology, vol. 1, pp. 343-352. Baltimore: Williams \& Wilkins.
Brock, T. D. (1984). Genus Thermus Brock and Freeze 1969, 295 $\mathrm{AL}$. In Bergey's Manual of Systematic Bacteriology, vol. 1, pp. 333-337. Baltimore: Williams \& Wilkins.

Brock, T. D. (1985). Life at high temperatures. Science 230, 132-138.

Claus, D. \& Berkeley, R. C. W. (1986). Genus Bacillus Cohn 1872, $174^{\mathrm{AL} *}$. In Bergey's Manual of Systematic Bacteriology, vol. 2, pp. 1105-1141. Baltimore: Williams \& Wilkins.

Drapeau, G. R., Matula, T. I. \& Macleod, R. A. (1966). Nutrition and metabolism of marine bacteria. XV. Relation of $\mathrm{Na}^{+}$activated transport to the $\mathrm{Na}^{+}$requirement of a marine pseudomonad for growth. Journal of Bacteriology 92, 63-71.

Fein, J. E. \& MACLeOD, R. A. (1975). Characterization of neutral amino acid transport in a marine pseudomonad. Journal of Bacteriology 124, 1177-1190.

Fiala, G., Stetter, K. O., Jannasch, H. W., Langworthy, T. A. \& Madon, J. (1986). Staphylothermus marinus sp. nov. represents a novel genus of extremely thermophilic submarine heterotrophic archaebacteria growing up to $98^{\circ} \mathrm{C}$. Systematic and Applied Microbiology 8, 106-113.

Forsberg, C. W., Costerton, J. W. \& MacLeod, R. A. (1970). Separation and localization of cell wall layers of a Gram-negative bacterium. Journal of Bacteriology 104, 1338-1353.

Huber, R., Langworthy, T. A., König, H., Thomm, M., Woese, C. R., Sleytr, U. B. \& SteTter, K. O. (1986). Thermotoga maritima sp. nov. represents a new genus of unique extremely thermophilic eubacteria growing up to $90^{\circ} \mathrm{C}$. Archives of Microbiology 144, 324-333.

Huber, R., Woese, C. R., Langworthy, T. A., Fricke, H. \& Stetter, K. O. (1989). Thermosipho africanus gen. nov., represents a new genus of thermophilic eubacteria within the 'Thermotogales'. Systematic and Applied Microbiology 12, 32-37.

Jannasch, H. W., Huber, R., Belkin, S. \& Stetter, K. O. (1988). Thermotoga neapolitana sp. nov. of the extremely thermophilic, eubacterial genus Thermotoga. Archives of Microbiology 150, 103-104.

Kristjansson, J. K., Hreggvidsson, G. O. \& Alfredsson, G. A. (1986). Isolation of halotolerant Thermus spp. from submarine hot springs in Iceland. Applied and Environmental Microbiology 52, $1313-1316$.

Kristuansson, J. K. (editor) (1992). Thermophilic Bacteria. Boca Raton: CRC Press.

KurR, M., Huber, R., König, H., Jannasch, H. W., Fricke, H., Trincone, A., Kristuansson, J. K. \& Stetter, K. O. (1991). Methanopyrus kandleri, gen. and sp. nov. represents a novel group of hyperthermophilic methanogens, growing at $110^{\circ} \mathrm{C}$. Archives of Microbiology 156, 239-247.

Kushwaha, S. C., Kates, M. \& Kramer, J. K. (1977). Occurrence of indole in cells of extremely halophilic bacteria. Canadian Journal of Microbiology 23, 826-828.

MaCFaddin, J. F. (1980). Biochemical Tests for Identification of Medical Bacteria. Baltimore: Williams \& Wilkins.

Miroschnichenko, M. L., Bonch-Osmolovskaya, E. A., Neuner, A., Kostrikina, N. A., ChernyCh, N. A. \& Alekseev, V. A. (1989) Thermococcus stetteri $\mathrm{sp}$. nov., a new extremely thermophilic marine sulfur-metabolizing archaebacterium. Systematic and Applied Microbiology 12, 257-262.

Neuner, A., Jannasch, H. W., Belkin, S. \& Stetter, K. O. (1990). Thermococcus litoralis sp. nov.: a new species of extremely thermophilic marine archaebacteria. Archives of Microbiology 153, 205-207.

ONISHI, H. (1972). Salt response of amylase produced in media of different $\mathrm{NaCl}$ or $\mathrm{KCl}$ concentrations by a moderately halophilic Micrococcus. Canadian Journal of Microbiology 118, 1617-1620.

PLEDGER, R. J. \& BAROSS, J. A. (1989). Characterization of an extremely thermophilic archaebacterium isolated from a black smoker polychaete (Paralvinella sp.) at the Juan de Fuca Ridge. Systematic and Applied Microbiology 12, 249-256.

Pledger, R. J. \& Baross, J. A. (1991). Preliminary description and nutritional characterization of a chemoorganotrophic archaeobacterium growing at temperatures of up to $110^{\circ} \mathrm{C}$ isolated from a submarine hydrothermal vent environment. Journal of General Microbiology 137, 203-211. 
Pley, U., Schipka, J., Gambacorta, A., Jannasch, H. W., Fricke, H., RACHel, R. \& STETter, K. O. (1991). Pyrodictium abyssi sp. nov. represents a novel heterotrophic marine archaeal hyperthermophile growing at $110^{\circ} \mathrm{C}$. Systematic and Applied Microbiology 14, 245-253.

REICHELT, J. L. \& BAUMANN, P. (1974). Effect of sodium chloride on the growth of heterotrophic marine bacteria. Archives of Microbiology 97, 329-345.

Rhuland, L. E., Work, E., Denman, R. F. \& Hoare, D. S. (1955). The behavior of the isomers of $\alpha, \varepsilon$-diaminopimelic acid on paper chromatograms. Journal of the American Chemical Society 77, 4844-4846.

SChleifer, K. H. \& Kandler, O. (1972). Peptidoglycan types of bacterial cell walls and their taxonomic implications. Bacteriological Reviews 36, 407-477.

ShieH, W. Y., Simidu, U. \& Maruyama, Y. (1987). Isolation of a nitrogen-fixing Vibrio species from the roots of eelgrass (Zostera marina). Journal of General and Applied Microbiology 33, 321-330.

Shieh, W. Y., Simidu, U. \& Maruyama, Y. (1988). Nitrogen fixation by marine agar-degrading bacteria. Journal of General Microbiology 134, 1821-1825.

SMIBERT, R. M. \& KRIEG, N. R. (1981). Systematics: general character- ization. In Manual of Methods for General Bacteriology, pp. 409-443. Washington, DC: American Society for Microbiology.

Stetter, K. O., Fiala, G., Huber, G., Huber, R. \& Segerer, A (1990). Hyperthermophilic microorganisms. FEMS Microbiology Reviews 75, 117-124.

Thompson, J. \& MacLeod, R. A. (1974). Specific electron donorenergized transport of $\alpha$-aminoisobutyric acid and $\mathrm{K}^{+}$into intact cells of a marine pseudomonad. Journal of Bacteriology 117, 1055-1064.

Thompson, J., Costerton, J. W. \& MacLeod, R. A. (1970). K ${ }^{+}$ dependent deplasmolysis of a marine pseudomonad plasmolysed in a hypotonic solution. Journal of Bacteriology 102, 843-854.

Windberger, E., Huber, R., Trincone, A., Fricke, H. \& Stetter, K. O. (1989). Thermotoga thermarum sp. nov. and Thermotoga neapolitana occurring in African continental solfataric springs. Archives of Microbiology 151, 506-512.

Wong, P. T. S., Thompson, J. \& MacLeod, R. A. (1969). Nutrition and metabolism of marine bacteria. XVII. Ion-dependent retention of $\alpha$-aminoisobutyric acid and its relation to $\mathrm{Na}^{+}$-dependent transport in a marine pseudomonad. Journal of Biological Chemistry 244, 1016-1025. 